\title{
The Creativity Skills of Auditory, Visual, and Kinesthetic Learners in Solving Cube and Cuboid Problems
}

\author{
Zakiatus Qurrotul A’yun ${ }^{1}$, Dwi Juniati ${ }^{2}$, Ismail ${ }^{3}$ \\ ${ }^{1}$ Surabaya, Surabaya State University, zakiatus.18010@mhs.unesa.ac.id \\ ${ }^{2}$ Surabaya, Surabaya State University, dwijuniati@unesa.ac.id \\ ${ }^{3}$ Surabaya, Surabaya State University, ismail@unesa.ic.id
}

\begin{abstract}
This study aims to describe the creativity skills of Junior High School students in solving cube and cuboid problems based on student learning styles. The research instruments used were creativity skills tests, a learning style questionnaire, and interviews. As many as three seventh graders who have different learning styles: visual, auditory, and kinesthetic, working on a cuboid/cube problem. Their performances on such a problem were then assessed regarding fluency, flexibility, and novelty. The results showed that the visual learner produced two different solutions with two different methods/strategies and completed his solution by providing a lot of illustrations/representations although they could not be categorized as novelty solutions. Meanwhile, the auditory learner provided two different solutions with two different methods/strategies. More particularly, he determined the appropriate size and found a suitable size by using a three-variable linear equation for the cube and cuboid problem although he produced some mistakes and uncompleted on the work procedures. Lastly, the kinesthetic learner provided two different solutions with one method/strategy, such as by directly determining the various correct sizes for the problem-solution although the answers could not be categorized novelty for creativity skill. Further studies are suggested to involve more participants to get a wider insight on the students' creativity for different learning styles.
\end{abstract}

Keywords: Creativity Skill, Cube and Cuboid, Learning Styles.

\section{Keterampilan Kreativitas Siswa Auditori, Visual, dan Kinestetik dalam Memecahkan Masalah Kubus dan Balok}

\begin{abstract}
ABSTRAK
Penelitian ini bertujuan untuk mendeskripsikan keterampilan kreativitas siswa SMP dalam menyelesaikan soal kubus dan kubus berdasarkan gaya belajar siswa. Instrumen penelitian yang digunakan adalah tes keterampilan kreativitas, angket gaya belajar, dan wawancara. Sebanyak tiga siswa kelas tujuh yang memiliki gaya belajar berbeda: visual, auditori, dan kinestetik, mengerjakan soal kubus / kubus. Penyelesaian masalah mereka pada soal itu kemudian dinilai berdasarkan kefasihan, fleksibilitas, dan kebaruan. Hasil penelitian menunjukkan bahwa siswa visual menghasilkan dua solusi yang berbeda dengan dua metode / strategi yang berbeda
\end{abstract}


dan menyelesaikan solusinya dengan memberikan banyak ilustrasi / representasi meskipun tidak dapat dikategorikan sebagai solusi baru. Sementara itu, siswaauditori memberikan dua solusi berbeda dengan dua metode / strategi berbeda. Lebih khusus lagi, ia menentukan ukuran yang sesuai dan menemukan ukuran yang sesuai dengan menggunakan persamaan linier tiga variabel untuk masalah kubus dan kubus meskipun ia menghasilkan beberapa kesalahan dan prosedur kerja yang tidak tuntas. Terakhir, siswa kinestetik memberikan dua solusi yang berbeda dengan satu metode / strategi, seperti dengan langsung menentukan berbagai ukuran yang benar untuk solusi masalah meskipun jawaban tersebut tidak dapat dikategorikan sebagai novelty untuk keterampilan kreativitas. Studi lebih lanjut disarankan untuk melibatkan lebih banyak peserta untuk mendapatkan wawasan yang lebih luas tentang kreativitas siswa untuk gaya belajar yang berbeda.

Kata Kunci: Keterampilan Kreativitas, Kubus dan Balok, Gaya Belajar.

\section{Introduction}

Problem solving was important when the students learn Mathematics. To accomplish it, the students required special skills called creativity skills. The research investigated the relationship between learning style and the students' creativity skills in solving the problem of cube and cuboid material. The skill of creativity itself belongs to one of $4 \mathrm{C}$ skills (Communication, Collaboration, Critical Thinking, and Creativity) which should be understood by the students in the 21 st century. Kereluik [1] suggests that the term $4 \mathrm{C}$ which belongs to meta-knowledge on the 21 st century was a fundamental knowledge about the process of working on basic skills which influence the students' success in this global era. Based on the results of Hakkinen's study [2], it is found that to be successful in this $21^{\text {st }}$ century, the students should be equipped with $4 \mathrm{C}$ skills and the ability to use the information and communication technology. In addition, the teachers were challenged to facilitate the students' ability to learn, to analyze and to solve the problems. The results of Setianingsih's research [3] that the 4C skills of students also can develop because students are facilitated to analyze problem, create and implement plans to solve problem, evaluate, identify, and implement the activities needed to correct the correct ones, and assess whether the desired results reached. Furthermore,

Based on the report of the computer-based National exam (UNBK) of Mathematics on Junior High School in Pasuruan, the students who answered correctly on UNBK showed that the score of geometry and measurement was still low compared to other test material for the last 4 years (2015-2019). Besides, the UNBK results showed that the students also have low score on the material of the solid geometry with flat side, especially on the indicator of calculating the volume of the solid geometry with flat side. The score was about 42.59 while a minimum score was 55 . The cube and cuboids materials were included in the solid geometry with flat side material. The students often need the implementation of mathematical visualizations on the material concerned with geometry [4]. Based on the low score above, it could be stated that the cube and cuboid material was still relatively low as well. Thus, it was necessary to investigate more deeply about how to learn it and how the students solve the problem.

As we know from condition of geometrical cognitive knowledge from Junior High School students in Pasuruan Regency and the result of studies before about 4C skills are skills that students must have in this $21^{\text {st }}$ century, those are the important and difference of this study. Furthermore, the researcher wants to know deeply the extent of creativity skill of students in Pasuruan Regency, which is creativity skill, is one of 4C skills and 
that's important in $21^{\text {st }}$ century, especially in cube and cuboid's material. By implementing 4C skills especially creativity skills in learning mathematics, the students were not only equipped with the knowledge of concepts, but also the skills that students can use when facing a problem/challenge in daily life.

The skill of creativity itself relates to the skill to find the idea/innovation through observation of a condition/problem $[5,6,7]$. The students' creativity skills in learning mathematics were more concentrate on creative thinking skills $[6,8]$. In line with this statement, the students were also required to explain how creative reasoning is when he solves the problem $[9,10]$. It happened because most of the activities which students learn about mathematics were thinking activities. In this study, the researcher used the criteria of creativity to identify the students' creativity skills. There were three criteria for determining the student creativity. Those were fluency, flexibility, and novelty [11]. The fluency is the students' skills in generating correct answers differ from problem solving. Flexibility means the student skills in generating methods/strategies from different problem solving. Furthermore, novelty deals with the students' skills in generating answers or methods/strategies which were uncommon to be used by the students at their cognitive development. How important the role of students' creativity skills could be analogous as a skill in implementing problem solving by providing various problems with different methods/strategies which were not commonly done at the level of their cognitive development.

The students need more ideas/innovations when they face the problems in the process of problem solving, especially in learning mathematics. Based on the result of Goldin's research, [12] it was noted that there were value considerations for prioritizing creativity and mathematical talent (or high proficiency) when the students faced trends/problems which should be considered seriously and study further. The teachers taught one way in problem solving and they see how to resolve the problem together. Even, when they gave the correct answer, they only gave more steps or they needed a longer time [13].

In the learning process, the students' learning style greatly affected their creativity skills when they did problem solving. The students' way in learning process was called learning style. Willing [14] stated that learning styles as a way of learning that's liked by learners. With the conditions/learning style preferred by the students, they have a tendency to adapt certain strategies in their learning process as a form of responsibility to obtain a learning approach which is appropriate to the demands of learning in class as well as the demands of the participants. In addition, the learning style demonstrated the students' way in processing information with the certain purposes and applying them. One of the theories of learning style with the sensory preference approach was known as the kinesthetic visual auditory learning style (VAK) [15]. VAK's learning style could be divided into three categories based on the sensory preference or brain-possessed ability to absorb, manage, and convey information. Those were visual learning style, auditory learning style, and kinesthetic learning style [15]. These three categories had certain characteristics [16]. This category became a guideline that the students have one of the most prominent characteristics so that if the students get a suitable stimulation in learning it will make them easier to comprehend the learning material [17]. Khodabakhshzadeh [18] expressed significant and positive predictions on the achievement of the students on creativity based on the VAK learning style. Based on the results of the research conducted by Sajedi [19], it was also known that there were significant differences in the level of creativity based on the students' learning style at Semnan University. So, it was advisable for the teachers to give attention to their students by forming the student's creativity through problem solving with a variety of appropriate methods/strategies. 
Based on the explanation above, an investigation on the students' creativity skill deeper when solving mathematical problems of cube and cuboids material is important particularly regarding students' learning style: visual, auditory, and kinesthetic. Thus, this study focus on the fluency, flexibility, and novelty of the problem solving from those three types of students.

\section{Method}

This was a qualitative descriptive research which aims to describe the creativity skills of Junior High School students in solving the problem of cube and cuboid material based on their learning style. The participants of this study was three students of Grade VIII at Junior High School 1 Pandaan-Pasuruan who had visual learning style, auditory style, and kinesthetic learning style. The researcher selected the participants by using purposive sampling method in which the selection of the participants consider some aspects to make the research process easier. For instance, the students should have a VAK learning style with the mathematical ability of the participants controlled equivalent. In addition, the researcher conducted discussions with the teachers about the students who had good communication as well.

In this study, there were two types of instruments used to collect the data. The first instrument is the researcher as the main instrument. The second instrument was a supporting instrument in the form of creativity skills test, VAK learning style questionnaire, and unstructured interview guidelines. Creativity Skills Test was a writing test designed to identify the skills of the students' creativity in solving contextual problems about the creation of the solid figure of cubes and cuboids from a plane figure of rectangle. This kind of test was validated by the experts. The creativity skills test given was as follows.

There was thick plywood in Andi's house with a size of $1 \mathrm{~m} \times 1.2 \mathrm{~m}$. The plywood would be used to make 2 charity boxes in the form of cubes and cuboids.

1. What was the length of the edges of the charity cuboid that might be formed? From these measurements, what were the area of the thick plywood used and the volume of it?

2. After being used to make a cube-shaped charity box, what were the length, width, and height of the cuboid-shaped charity box that might be formed? From these measurements, what were the area of the thick plywood used and the volume of it?

3. Were there different sizes for the two charity boxes? Calculate the area of plywood used and the volume of the two charity boxes with different sizes and solutions than what you have found before!

Note: The size of the smallest cube-shaped charity box that can be used is the length of the edges $=10 \mathrm{~cm}$ and the size of the smallest cuboid-shaped charity box that can be used is length $=11 \mathrm{~cm}$, width $=10 \mathrm{~cm}$, and height $=10 \mathrm{~cm}$.

The VAK Learning Style questionnaire was a questionnaire to determine the students' learning style based on their visual learning style, auditory learning style, and kinesthetic learning style. The learning style questionnaire used in the study was developed by Chislett \& Chapman [20]. Unstructured interview was the interview conducted to get the information deeper (free interviews) given by the students to complete data.

The technique to collect the data used in this study was conducted by giving VAK questionnaire to 33 students on Grade 8 students at a junior high school at Pasuruan, 
Indonesia. Then, they were given creativity skills test. The researcher chose three students to do unstructured interviews became selected participants based on the mathematical capabilities and good communication of the participants to obtain more information from the participants' answers. Data analysis was conducted by describing the criteria of creativity skills shown by the participants. After that, the researcher implemented triangulation method from the test and unstructured interviews to get valid data. There were three criteria/indicators for describing the students' creativity skills, such as fluency, flexibility, and novelty. The JHS' students shown in fluency when those students' skills in generating correct answers differ from other problem solving (min. mention 2 difference correct answer). Flexibility when the students shown in generating methods/strategies from different problem solving (min. mention 2 difference methods/strategies). Novelty deals when the students' skills in generating answers or methods/strategies which were uncommon to be used by the JHS' students at their cognitive development. The uncommon answers/methods showed when students do not solve problem solving that are often done by JHS students' level cognitive, for example students usually solve the system of two-variables linear equation by eliminationsubstitution methods, but student who have novelty skill can use matrix methods or others methods which are not taught on JHS level or the originality methods from students.

\section{Results and Discussion}

Based on the result of the learning style poll, it was known that 17 students had visual learning style, 13 students had auditory learning style, and 3 students had kinesthetic learning style. From the results of the learning style questionnaire and the test of creativity skills, the researcher selected three subjects consisting of 1 student who has a visual learning style, 1 student who has auditory learning style, and 1 student who has a kinesthetic learning style. Based on the results of the data analysis done by the researcher, the researcher presented these following discussions dealing with the creativity skills of junior high school students in solving the cubes and cuboids problems based on their learning styles.

\subsection{Results}

\subsubsection{The Students' Creativity Skills with Visual Learning Style}

Based on the research and criteria of the creativity skills, here were results about the students' creativity skills that had a visual learning style in solving the problem of cubes and cuboids material. Here were the students' answers that had a visual learning style (S1) of the creativity skills test results. 


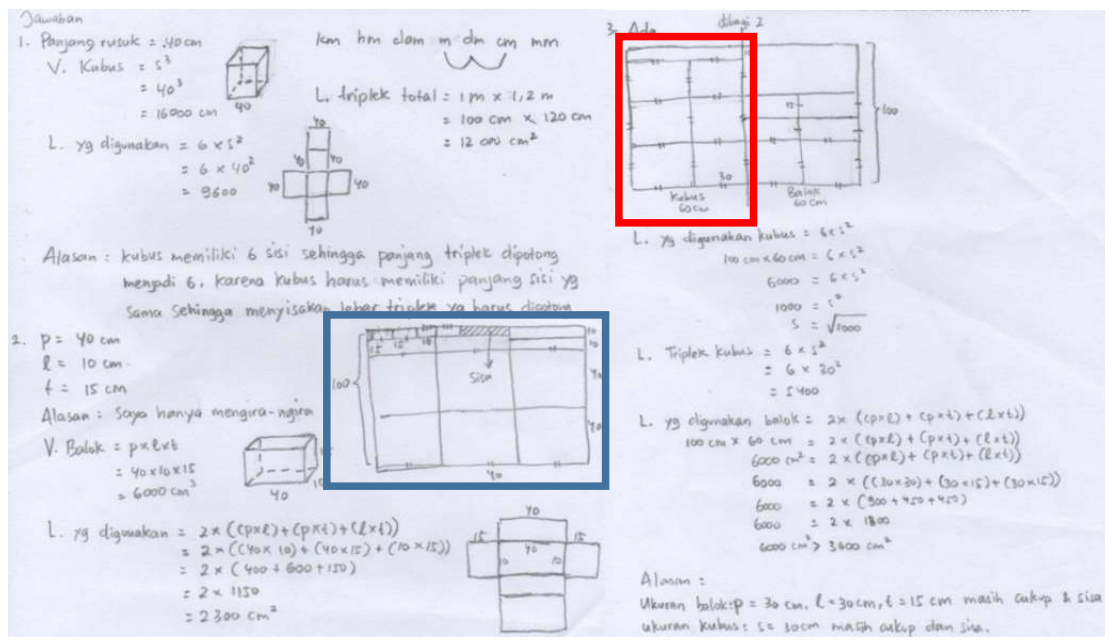

Figure 1 Visual learners' work

Based on Figure 1, the participant 1 shown on her answer sheet that she answered all the questions. S1 gave 2 different correct answers and 2 different methods/strategies from given problem. S1 used representations/sketches to help her solve the problem. Those answers are correct, because S1 mention sizes which are we can make/solve the correct problem solving, such as S1 can make two types of charity boxes with different sizes. S1 also thorough by giving unit for every calculation and give argumentations for reinforcement of her analysis.

After the test was given, the interview was conducted. Here were the results of the interviews with $\mathrm{S} 1$ on his answer sheet.

$\mathrm{Q}$ : Question number 1, how did you get the edge length $=40 \mathrm{~cm}$ ?

S1: I saw that the grid of the cube had 6 equal sides and I saw that the area should be left over to make a box of charity.

Q : Why did you draw a cube and nets of cube on your answer on number 1 ?

S1: To make it easier for me, to determine the volume, and to determine the area that would be used.

Q : Question number 2, how could you be sure if the size you specified did not exceed the size of the remaining plywood?

S1: I drew this (pointing to the blue box at Figure 1). So, I guessed the right size and found out if there were plywood leftover and not more in size.

Q : Question number 3, how did you get another measurement for the problem solving?

S1: I drew it into 2 parts, one for the cube-shaped charity box and the other for the cuboid charity box. After that, I matched the size in the image.

Q : Try to explain from your answer for the size of the charity cube box from question number 3 of these! How did you find the length of the side of the cube $=30 \mathrm{~cm}$ ?

S1: So, I divided one part for the charity cuboid into 2 equal parts, $60 \mathrm{~cm} \div 2=30 \mathrm{~cm}$, and I saw that there were some remaining parts. So, I used the length of the edge $=$ $30 \mathrm{~cm}$.

Q : How did you get the size of the cuboid charity box on the question number 3 ?

S1: I calculated it by using the formula for the surface area of the cuboid. Then, I entered the size and it turned out that it is still smaller than the surface area of the cuboid.

Based on answer of test and the interview results, S1 could solve the problem well by using the figure to provide solutions from problem solving. The participants with this visual learning style can understand the problem by being able to make a plan through visualizing/sketching the pictures of plywood pieces which will be arranged to make a charity box. For the answer to the question number 1, S1 drew up a space cube to help 
the calculation of the volume and the grid of the cubes and to help the calculation of the area of the plywood used. At the calculation of the volume and area of the plywood which is used, S1 assumes the volume of cubes with V. for Cube and L. were used. S1 also used it to draw a cube and grid that he assumed it had an actual edge length of $40 \mathrm{~cm}$. For the answer to Question number 2, S1 still used the same method/strategy as number 1, but it was convincing if the answer was correct with the representation/sketch of plywood pieces as in the blue box in Figure 1. S1 assumed the picture in the blue box was an overview of the size of the actual thick plywood. S1 sketched by bearing the size of each piece he assumed as the actual size of the thick plywood, so that when the thick plywood was cut into a charity box later, student could cut it based on the actual size sketches which can be seen from the picture. The method/strategy used by S1 on number 1 and 2 is reasonable and precise. In addition, $\mathrm{S} 1$ could give explanation in detail how he found the problem solving using method/strategy estimated by trying to determine the appropriate size with the help of picture.

To answer the question number 3, S1 could show different methods/strategies by providing different sizes and sketches from number 1 and 2 (see the red and blue box on the Figure 1). The answer signifies that $\mathrm{S} 1$ has demonstrated the criterion of the fluency and flexibility of the creativity skills, but the answers/methods used were still not included in the novelty, because the methods are often/commonly used by JHS' students (see explanation of criteria/indicators' creativity in the last paragraph of method). S1 gave a reason/argument which makes sense on the problem solving which she does. S1 assumes thick plywood by drawing a rectangle and has an actual size in the sketch number 3 with the 100 for its width and $120 \mathrm{~cm}$ for its length. S1 made a vertical line in the middle of the long size to divide 2 parts of the thick plywood so that the plywood can be used and there is no connection of some thick plywood pieces. From the problem solving above, it was known that $\mathrm{S} 1$ could produce two different solutions of the problem given. S1 applied two different methods/strategies: determining the appropriate size and trying to divide the same size for cubes and cuboids by using sketches. This answer cannot be categorized in novelty because the method/strategy is commonly used by students in junior high school level.

\subsubsection{The Students' Creativity Skills with Auditory Learning Style}

Based on the research and criteria of the creativity skills, the explanation below was the result of students' creativity skills that had auditory learning style in solving the problem of cubes and cuboids material. Here were the answers of students who had auditory learning style (S2) from the results of creativity Skills test. 


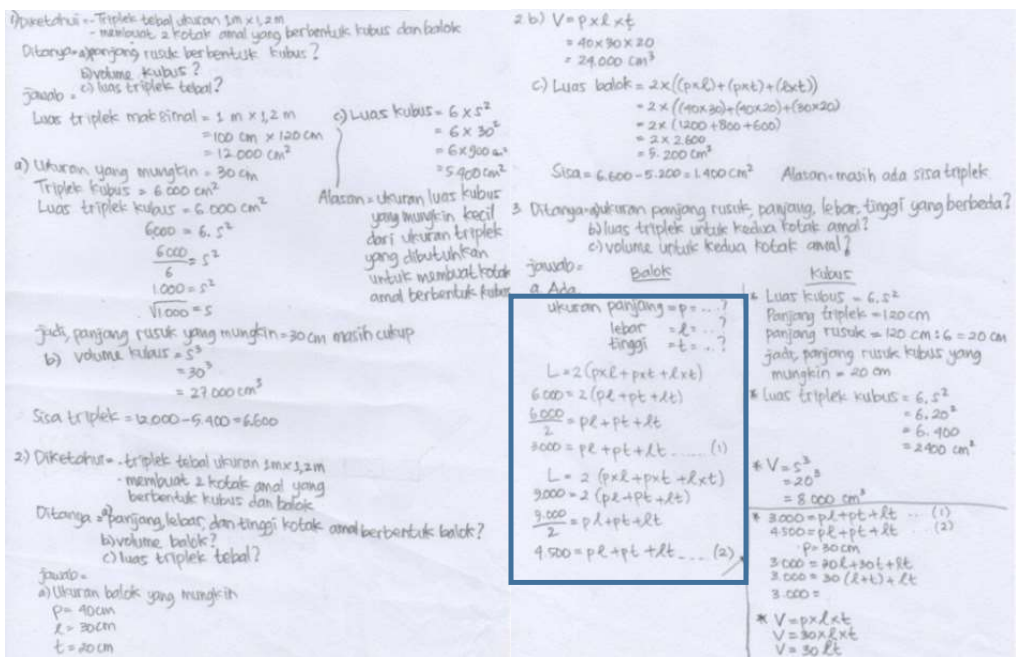

Figure 2 Auditory learner's work

Based on Figure 2, the participant 2 shown that S2 gave 2 different correct answers and 2 different methods/strategies, but one of the methods is uncompleted on work procedure. S2 could show answered all the questions, but in answering number 3 shown uncompleted methods and S2 directly shown the sizes of problem solving. S2 used surface area of each shape and three-variable linear equation approach to help solving the problem. Those given sizes from S2's problem solving are correct, because S2 mention sizes which are we can make/solve two charity boxes on cube and cuboid-shaped. S2 also thorough by giving unit at the end of calculation and give argumentations for reinforcement of the analysis.

After the test was given, the interview was conducted. Here were the S2's interviews results on his answer sheet.

$\mathrm{Q}$ : Question number 1, how did you get the length of the edges $=30 \mathrm{~cm}$ ?

S2: I used the formula for the surface area of a cube to determine the size of the cubeshaped charity box and I calculate its area and there is remaining space to make a charity box in the form of cuboids.

Q : Why did you choose the length of the edges which may be $=30 \mathrm{~cm}$ from your calculation in answering number 1 ?

S2: I chose the approximate number to calculate volume and surface area easily.

$\mathrm{P}$ : Question number 2, how did you get these measurements? Were you sure if the size you specify does not exceed the size of the remaining plywood?

S2: I liked to measure the volume and surface area of the cuboids and there were plywood leftovers. Thus, the size was right.

$\mathrm{P}$ : Question number 3, how did you get another measurement for the problem solving?

$\mathrm{S} 2$ : I took the size of the length $=p$, width $=l$, and height $=t$, because I didn't know how many sizes which could be used, I calculated it by using the maximum area of the plywood. However, I couldn't find the answer.

Q : Where did you explain the numbers 3,000 in equation 1 and 4,500 in equation 2?

$\mathrm{S} 2$ : The equation 1 came from $12,000 \div 2=6000$ then I used it to the surface area formula. Instead of 4500, I am looking for another number.

$\mathrm{P}$ : How did you get the size in determining the size of the cube-shaped charity box in the question number 3 ?

S2: I calculated it from the length of the plywood $=120 \mathrm{~cm}$ then I divided it by 6 . So the possible edge length $=20 \mathrm{~cm}$.

$\mathrm{Q}$ : Why did you divide it by 6 for the length of the plywood $=120 \mathrm{~cm} \div 6=20 \mathrm{~cm}$ ? 
S2: It was because the cubes had 6 equal sides

Based on the Figure 2 and the interview results, the characteristic of auditory style shown by the participant with this auditory style of learning was good in delivering his idea, but it was difficult to write down something on his mind to solve a given problem. To answer the question number 1, S2 determines the size of the problem solving by calculating the cube surface area. Thus, it could be concluded that the specified size could be used for problem solving. The use of the surface area of the cube could be interpreted that S2 understood the problem given and provide the right solution. Since the thick plywood area was known, S2 calculated the length of the edges which were probably the length of the edges that were not exceeding from $\sqrt{1000} \mathrm{~cm}$ and S2 estimated the length of the edges is still enough to be made. Then, S2 gives the arguments about the remaining thick plywood by counting it from the area of plywood that has not been cut. Furthermore, to answer the question number 2, S2 applied the same method/strategy as number 1, but she immediately determines the size which may be used to make a charity box in the shape of cuboids and S2 believes that the answer was correct by calculating the remaining plywood area after being used to create a cube-shaped charity box and cuboid. S2 gave the same argument to answer question number 1 about the remaining thick plywood already used. S2 was difficult to explain/write her arguments with words. Method/strategy that S2 used on number 1 and 2 were plausible and could be used, but she could not give the explanation in detail how she found her method/strategy, so that she directly used the method to determine the appropriate size.

Besides, to answer the question number 3, S2 could provide different methods/strategies by giving different sizes of number 1 and 2 (see the blue box). The answer signified that she demonstrated the criterion for the fluency, flexibility, and novelty of the criteria of creativity skills, but the answer/method used is still not perfect because of an error in her work procedure and she is unable to continue his calculations. Her method/strategy was quite reasonable. She realized that it was important to write what size was suitable for length by writing $p$, width with $l$, and height with $t$. From the Figure 2 it appears that S2 shows its versatility by giving different sizes through the formation of Equation 2. After that, S2 tried counting it by specifying the length for the box shaped cuboid equal to $30 \mathrm{~cm}$, but she cannot do it. In calculating the volume, she also does the same way as the previous calculation of the plywood used. The method/strategy used is quite absurd, we cannot use the way to work around this problem, but we can use the problem solving by writing the length $=p$, width $=l$, and height $=t$. From the problem solving above, it could be said that S2 could produce two different solutions of the given problem. She applied two different methods/strategies, such as determining the appropriate size and finding a suitable size using a three-variable linear equation. This answer could be categorized in novelty as the method/strategy since she demonstrates the use of a three-variable linear equation learned in high school, but there was an error and uncompleted in its working procedure.

\subsubsection{The Students' Creativity Skills with Kinesthetic Learning Style}

Based on the criteria of the creativity skills, the explanation below was the result about the students' creativity skill that has a kinesthetic learning style in solving the problem of cube and cuboids material. Here were the answers of the students who have a kinesthetic learning style (S3) from the creativity skills test results. 


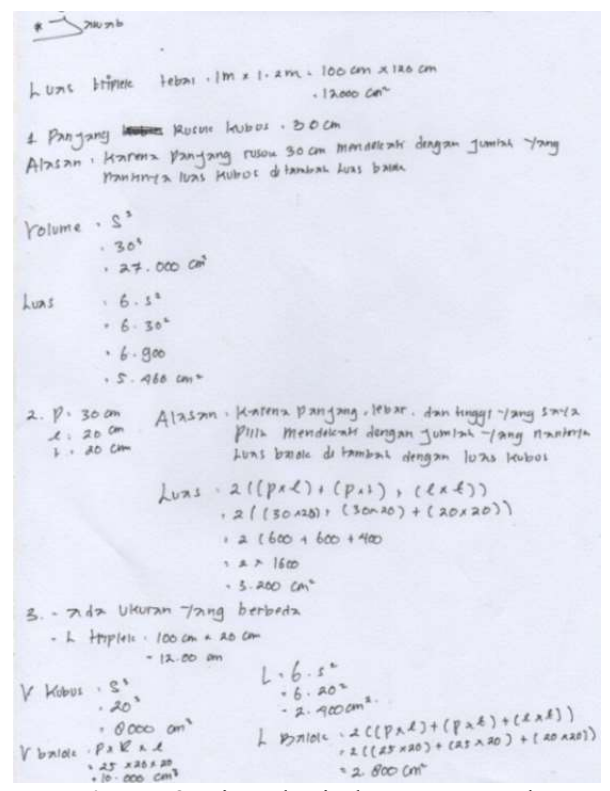

Figure 3 Kinesthetic learner's work

Based on Figure 3, the participant 3 shown that S3 gave 2 different correct answers with same methods/strategies, such as S3 shown directly determine the sizes of two charity box in cube and cuboid-shaped. S3 used surface area of each shape as hypothesis to determine the problem solving. Those given sizes for problem solving are correct, because S3 mention sizes which are we can make/solve two charity boxes on cube and cuboid-shaped. S3 also thorough by giving unit at the end of calculation, but S3 not give argumentations for reinforcement of her work. In those problems solving, S3 only show the fluency of creativity skill. It's hard to find the flexibility and novelty from the creativity skill test of S3, then the researcher interviewed the participant to get deep information/argumentation from her work to know the creativity skill of kinesthetic learning styles. The following interviews were the results of the S3 answer written on her answer sheet.

Q : Question number 1, how did you get the length of the edges $=30 \mathrm{~cm}$ ?

$\mathrm{S} 3$ : Since the length of the edges $=30 \mathrm{~cm}$, it is calculated based on the area of the plywood, the result is approximate when it is added to the area of the plywood for the charity cube and cuboid.

Q : How could you be sure that the size you mentioned can approximate the result if you add up the area of the charity cubes plywood?

S3 : By calculating the volume and area of the cube-shaped charity box.

Q : For question no. 2, how could you be sure if the size you specified did not exceed the size of the remaining plywood?

S3 : I counted it and it was just right that the size was no more than the size of thick plywood.

Q : Did you try to determine the size for the answer to question number 2?

S3 : Yes, I tried to determine the size and then I counted it.

$\mathrm{Q}$ : How did you get another measurement of the problem in answering the question number 3?

S3 : I immediately determined the size and I counted it no more than the area of thick plywood.

$\mathrm{Q}$ : Were you in a hurry to solve the problem?

S3 : Yes, I wanted to finish it immediately. 
Based on written test and the interview results, it was known that S3 could provide solutions from problem solving. The characteristic of kinesthetic learning style shown by the participant with this learning style was in a hurry to do other things and a lot of physical motion that she is showing. To answer the questions number 1 and 2, S3 immediately determines the size of the charity box to be created. She believed that the answer was correct by calculating the area of plywood used for both boxes of charities. The method/strategy used by S3 was plausible because it immediately determined the size which was considered appropriate but when she was asked for more details about the method/strategy, it was difficult for her to explain the process of problem solving (difficult to argue) and she tended to use body language. Thus, it was difficult to trace the reason/argument in determining the size.

To answers questions number 3, S3 could provide the answers of different sizes from number 1 and 2, but S3 applied the same method/strategy as the previous question number. The answer signified that S3 demonstrated the fluency criteria of the creativity skills, but the answers/methods used were still the same and were not included in novelty. Thus, S3 did not demonstrate the versatility of its creativity skills yet. From the problem solving above, S3 could produce two different solutions from the problem given. S3 used one method/strategy which determined the appropriate size. This answer could not be categorized in novelty since the method/strategy was commonly done at the level of cognitive development of junior high school students.

\subsection{Discussion}

The results showed that the visual learning styles' student (S1), the auditory learning styles' student (S2), and kinesthetic learning styles' student (S3) had different answer and problem solving methods/strategies. On the question number 1, S2 and S3 mentioned the same size (solution of the problem), but they had a method/strategy which was quite different to provide problem solving. S1 and S2 answers were more detailed and analytic than S3 answers that directly determine their size. The S1 answer differs from S2 and S3, such as $\mathrm{S} 1$ further explains its problem solving methods/representations in resolving the problem correctly and in more detail using representations. Meanwhile, S2 explained the $\mathrm{method} / \mathrm{strategy}$ of solving the problem more analytic using formula surface area of cube and S3 determining the problem solving by hurried and directly the answer that she considers to be correct and suitable for solving the problem. From answer number 2 indicates the students provide varying lengths, widths, and heights (different problem solving solutions). All the students also gave the same method/strategy as number 1, but $\mathrm{S} 1$ added a sketch to clarify what she wanted. S1 is more detailed and orderly than S2 and S3.

From the answer number 3, it was known that the three participants could provide different sizes (different problem solving solutions) from both previous numbers. S1 shows easier in remembering and evaluating the problem based on what is visually seen and able to make plans and organize further well. The criteria for the fluency and flexibility of S1 can be present by giving answers and different methods/strategies from answers number 1 and 2. For S2 had difficulty to write down the final answer of the completion, but very smoothly in speaking and analyzing orally. The criteria of the fluency, flexibility, and novelty of S2 can be present by giving answers and different methods/strategies from answers number 1 and 2, but for the novelty criteria there is still not appropriate because there is an error in the working procedure and not yet perfect answer. In S3, she showed that she wanted to quickly finish what she was working on so that she felt noticed by others. At the time an S3 interview also showed more physical 
motion and liked learning through practice directly. The criteria of this S3 fluency can be present by providing different answers from answers number 1 and 2 .

In the process of solving problems, the student who had a visual learning style showed the characteristics of a visual learning style in the work of which is that it can perform regular, detailed, and thorough problem solving with the marked able to make a plan and long-term well arranged through the sketch of the thick plywood pieces. The sketch applied the strategies by dividing each side of cube in grid on the plywood. In addition, the student is also easier to remember something based on image associations. Student who had a style of auditory learning demonstrated the characteristics of auditory styles in their problem solving which was good in speech, but this student faced a difficulty in writing what did she mean on problem solving. It was known from her explanation delivered orally of what she meant and was very fluent in speaking. Besides, the student who had a kinesthetic learning style demonstrated characteristics in the problem solving which was the difficult to sit for long time, so that she did the task quickly to do the problem solving. Another characteristic for the student who had a kinesthetic learning style was she used many kinds of body language to express the opinions.

In this study, the students' creativity skills were reviewed from visual learning styles, auditory learning styles, and kinesthetic learning styles that could be seen clearly in their difference. The results of this research was in line with the research results conducted by Maselo [14] which showed that there were characterizing differences in high-level education students who have visual learning style, auditory learning style, and kinesthetic learning style when conducting online learning. Sitar [21] also mentions that there was a relationship between the results of creativity and learning style from the students.

\section{Conclusion}

Based on the analysis results and discussion, it could be concluded that student who had a visual learning style showed two criteria of the creativity skills of Junior High School students in solving the problem of cubes and cuboids material. Those were fluency and flexibility. The answer of student who had visual learning style could not be categorized in novelty since the method/strategy was commonly used by students in junior high schools, such as determining the appropriate size and trying to divide the same size for cubes and cuboids using representations/sketches. The student with auditory learning style demonstrated the creativity criteria were fluency, flexibility, and novelty. It was known that there were two different methods/strategies used, such as determining the appropriate size and finding a suitable size using a three-variable linear equation. For the novelty of student with the auditory learning style demonstrated it by using a system of three-variable linear equations learned in high school, but there were errors and uncompleted in the work procedures. The student of kinesthetic learning style shown the criteria of the creativity skills were only fluency since provides two different solutions with one method/strategy used, namely determining the appropriate size.

\section{Acknowledgement}

The authors would like to give appreciation for all people who provided advice, motivation, and opportunity for the research. The deepest appreciation also goes to Surabaya State University and Junior High School 1 Pandaan - Pasuruan which has been giving permission and opportunity for conducting this study. 


\section{References}

[1] Kereluik K, Mishra P, Fahnoe C and Terry L, "What knowledge is of most worth" J. of Digital Learning in Teacher Educ., vol. 29 no. 4, pp. 127-140, 2014.

[2] Häkkinen P, et al, "Preparing teacher-students for twenty-first-century learning practices (PREP 21)," Teachers and Teaching, vol. 23, pp. 25-41, 2017.

[3] Setianingsih R, "Implementasi pendekatan pembelajaran matematika realistik untuk mengembangkan keterampilan 4C siswa sekolah dasar," Proc. Seminar National Mathematics Education, Malang. pp. 524 - 536, 2016.

[4] Utomo E. S., Juniati D, and Siswono T. Y. E, "Mathematical visualization process of junior high school students in solving a contextual problem based on cognitive style" AIP, vol. 1868, 2017.

[5] Ebert M, et al, "Teaching emotion and creativity skills through art," The Int. J. of Creativity \& Problem Solving, vol. 25, no. 2, pp. 23-35, 2015.

[6] Hussen S, et al, "Combinatorial thinking and creativity skills in solving a coloredsquare paving decoration problem," J. of Physics vol. 1211, pp. 1-12, 2019.

[7] Celik A, "The organizational creativity skills of sports directors based on some demographic varibles," Int. J. of Human Sciences, vol. 11 no. 2 pp. 1224-1235, 2014.

[8] Isyrofinnisak F, Kusmayadi T A and Fitriana L, "Mathematics creativity skill of student in junior high school based on students thinking styles" J. of Physics, vol. 1538, 2019.

[9] Palengka I, Juniati D and Abadi, "Creative mathematical reasoning of prospective teacher in solving problems reviewed based on working memory capacity" $J$. of Physics, vol. 1417, 2019.

[10] Rosidah, Budayasa I K and Juniati D, “An analysis of statistical reasoning process of high school students in solving the statistical problem" J. of Physics vol. 1028, 2018.

[11] Silver E. A, "Fostering creativity through instruction rich in mathematical problem solving and problem posing," ZDM: The Int. J. on Math Educ., vol. 29, pp. 75-80, 1997.

[12] Goldin G. A, "Mathematical creativity and giftedness: perspective in response," ZDM: The Int. J. on Math Educ., vol. 49, pp. 147-157, 2017.

[13] Sternberg R. J, "School mathematics as a creative enterprise" ZDM: The Int. J. on Math Educ., vol. 49, pp. 977-986, 2017.

[14] Willing K, "Learning Styles in Adult Migration Education," Adeliade, Australia: National Curriculum Resource Center, 1988.

[15] Lujan H. L. and DiCarlo S. E, "Gender differences in learning style preferences among undergraduate physiology students," Advances in Physiology Educ., vol. 30, pp. 153-157, 2007.

[16] Hardaker G, Sabki A and Dockery R, "Cognitive learning styles and digital equity: searching for the middle way," Int. J. Incl. Educ., vol. 14 no. 8 pp. 777-794, 2010.

[17] Messick S, "The nature of cognitive styles: problems and promise in educational practice" Educ. Psychol., vol. 19 pp. 59-74, 1984.

[18] Khodabakhshzadeh H, Hosseinnia $M$ and Rahimian S, "Learning styles, metacognition, and creativity as predictors of the foreign language achievement," Psychol. Stud,. vol. 62 pp. 377-385, 2017.

[19] Sajedi R, "The study of relationship between learning styles and level of creativity among students in semman university of medical sciences," Int. J. of Sci. Management and Development, vol. 2 no. 11, pp. 646-651, 2014. 
The Creativity Skills of Auditory, Visual, and Kinesthetic Learners in Solving Cube and Cuboid Problems

[20] Chislett V. M. and Chapman A, "VAK test questionnaire", p. 1-5, September 2, 2020. [Online]. Available: https://www.businessballs.com/. [Accessed September 2, 2020].

[21] Sitar A. S, Cerne M, Aleksic D, and Mihelic K. K, "Individual learning styles and creativity," Creativity Research J., vol. 28, no. 3, pp. 334-341, 2016. 